\title{
BMJ Open Burn-out syndrome in Spanish internists during the COVID-19 outbreak and associated factors: a cross- sectional survey
}

\author{
Cristina Macía-Rodríguez (10 ,,2 Álvaro Alejandre de Oña, ${ }^{2,3}$ \\ Daniel Martín-Iglesias, ${ }^{2,4}$ Lucía Barrera-López, ${ }^{2,5}$ María Teresa Pérez-Sanz, ${ }^{2,3}$ \\ Javier Moreno-Diaz, ${ }^{2,6}$ Adriana González-Munera ${ }^{2,3}$
}

To cite: Macía-Rodríguez C, Alejandre de Oña Á, MartínIglesias D, et al. Burn-out syndrome in Spanish internists during the COVID-19 outbreak and associated factors: a crosssectional survey. BMJ Open 2021;11:e042966. doi:10.1136/ bmjopen-2020-042966

- Prepublication history and supplemetal material for this paper is available online. To view these files, please visit the journal online (http://dx.doi org/10.1136/bmjopen-2020042966).

Received 23 July 2020 Revised 28 December 2020 Accepted 13 January 2021

\section{Check for updates}

(C) Author(s) (or their employer(s)) 2021. Re-use permitted under CC BY-NC. No commercial re-use. See rights and permissions. Published by BMJ.

For numbered affiliations see end of article.

\section{Correspondence to} Cristina Macía-Rodríguez; cristina.macia.rodriguez@gmail. com

\section{ABSTRACT}

Objectives The objective of this study is to evaluate the impact of the COVID-19 outbreak on mental health and burn-out syndrome in Spanish internists and the factors that could be related to its appearance.

Design We performed an observational, cross-sectional, descriptive study for which we designed a survey that was distributed in May 2020.

Setting We included internists who worked in Spain during the COVID-19 outbreak.

Participants A total of 1015 internists responded to the survey. Of those $62.9 \%$ were women.

Results Of 1015 people, $58.3 \%$ presented with high emotional exhaustion, $61.5 \%$ had a high level of depersonalisation and $67.6 \%$ reported low personal fulfilment. $40.1 \%$ presented with the 3 criteria described, and therefore burn-out syndrome.

Burn-out syndrome was independently related to the management of patients with SARS-CoV-2 (HR: 2.26; $95 \% \mathrm{Cl} 1.15$ to 4.45 ), the lack of availability of personal protective equipment (HR: $1.41 ; 95 \% \mathrm{Cl} 1.05$ to 1.91), increased responsibility (HR: $2.13 ; 95 \% \mathrm{Cl} 1.51$ to 3.01 ), not having received financial compensation for overtime work (HR: $0.43 ; 95 \% \mathrm{Cl} 0.31$ to 0.62 ), not having rested after 24-hour shifts (HR: $1.61 ; 95 \% \mathrm{Cl} 1.09$ to 2.38 ), not having had holidays in the previous 6 months (HR: 1.36; $95 \% \mathrm{Cl} 1.01$ to 1.84 ), consumption of sleeping pills (HR: $1.83 ; 95 \% \mathrm{Cl} 1.28$ to 2.63 ) and higher alcohol intake (HR: $1.95 ; 95 \% \mathrm{Cl} 1.39$ to 2.73 ).

Conclusions During the COVID-19 outbreak, $40.1 \%$ of Internal Medicine physicians in Spain presented with burn-out syndrome, which was independently related to the assistance of patients with SARS-CoV-2, overworking without any compensation and the fear of being contagious to their relatives. Therefore, it is imperative to initiate programmes to prevent and treat burn-out in frontline physicians during the COVID-19 outbreak.

\section{INTRODUCTION}

The current pandemic caused by SARS-CoV-2, a new Betacoronavirus that appeared in December 2019 in Wuhan (China), ${ }^{1}$ has been a stressful period that has put healthcare systems and their professionals under
Strengths and limitations of this study

- We present the results of the largest study dealing with burn-out syndrome in Spanish internists due to the COVID-19 outbreak.

- The survey was specifically designed for this study, so it has not been previously used or validated.

- This study has been carried out through a voluntary online survey so it is possible that the most affected doctors were most interested in answering the survey questionnaire, which may constitute a bias.

- The survey was anonymous so we do not have data about the people who accessed the form but did not fill it in.

considerable pressure. $^{2}$ This illness can present with a range of symptoms, although fever and cough are the most common ones (mimicking SARS-CoV). The commonness of these symptoms, together with the different imaging patterns exhibited by the illness, complicates the diagnosis. ${ }^{3}$ The first case in Spain was diagnosed on 21 February 2020, with a subsequent exponential growth in the number of diagnoses that has affected more than 250000 people in Spain by May $2020 .^{5}$

Burn-out is a psychosocial syndrome that has a high prevalence ${ }^{6} 7$ in health professionals all over the world. It occurs in response to stressful situations during the development of a work activity. The first description of burn-out syndrome was made in 1974 by Freudenberger $^{8}$ and, later, it has been extensively studied by Maslach. ${ }^{9}$ Currently, it has become a very common problem in daily clinical practice. Depersonalisation, emotional exhaustion and a sense of reduced personal accomplishment are its main characteristics. ${ }^{9}$ This syndrome is closely related to work overload, age, poor work environment, lack of leadership, inequity, negative feedback and 
whether someone has received threats. ${ }^{7} 1011$ The most validated scale to quantify it is called the Maslach Burnout Inventory. ${ }^{12}$ A recent publication in Spain has revealed that more than a third of Internal Medicine specialists suffer from burn-out syndrome. ${ }^{10}$ Moreover, it has been shown that in several other countries more than an a half of the residents suffer from burn-out syndrome. ${ }^{13}$

A few studies have evaluated stress and burn-out syndrome in health workers during the COVID-19 outbreak, finding an increase in stress levels, ${ }^{14-17}$ with the exception of a single Chinese analysis that found less burn-out syndrome prevalence in people who worked on the front line compared with people performing usual ward work during the pandemic in Wuhan. ${ }^{18}$

The objective of this study is to evaluate the impact of the COVID-19 outbreak on mental health and burn-out syndrome in Spanish internists and the factors that could be related to its appearance.

\section{METHODS}

For this study we designed a survey using the Google Forms application. The survey was specifically designed for this study by a group of Spanish internists with representation of all ages and work positions. The first part of the survey has not been previously used or validated. The second part of the survey corresponds to the Maslach Burnout Inventory, a questionnaire that has been validated to identify burn-out in health professionals. ${ }^{12}$ The survey consisted of the following sections:

- Demographic variables: age, sex, marital status, and whether the person had children in their care or lived with older people.

- Work conditions: type of contract, type of hospital, type of work performed, compliance with established work hours, commute time to the workplace and means of transportation, vacations in the previous 6 months, rest after night shifts and 24-hour shifts, and 48 hours of rest per week. Additionally, it has been studied whether people had practised sports or other leisure activities during their free time.

- Change in work and lifestyle conditions due to the COVID-19 outbreak: assistance to patients with SARS-CoV-2 infection, confirmed personal SARS-CoV-2 infection, access to personal protective equipment (PPE), increased responsibility, increased working hours, financial compensation for overtime work, fear of infecting their families and change of place of residence to avoid it. Moreover, we studied the change in the pattern of tobacco or alcohol consumption, and the need for sleeping pills.

- Maslach Burnout Inventory: Human Services Survey for Medical Personnel in Spanish. It consists of 22 questions, 9 of which refer to emotional fatigue, 5 to depersonalisation and 8 to personal fulfilment. Burn-out syndrome was defined as high emotional exhaustion, a high level of depersonalisation and low level of personal accomplishment. ${ }^{12}$

\section{Participants and public involvement}

A group of participants, who represented all ages and work positions, were involved in the design of the first part of the survey.

\section{Participants}

The survey was distributed in May 2020 through the mailing list of the members of the Spanish Society of Internal Medicine (SEMI) and through SEMI's social networks (Facebook, Twitter and Instagram). We only included internists who worked in Spain during the COVID-19 outbreak. We excluded retired people, medical students and internists who worked in a country other than Spain.

The SEMI had 6331 members at the time of the survey. The sample size needed considering a prevalence of burn-out in Spanish internists of 30\%, ${ }^{10}$ a precision of the study of $3 \%$, a confidence level of $95 \%$ and a missing rate of $15 \%$ is 924 responders. One thousand four hundred and ninety-seven internists accessed the form and 1015 of them filled it in. The distributions of sex and age of the people who replied are comparable to the distributions containing the data of all the members of SEMI. All the autonomous communities in Spain are represented in the data.

\section{Statistical methods}

A descriptive analysis was performed by calculating the rates of qualitative variables and the median and $\mathrm{IQR}$ for the continuous variables. In order to find the variables associated with burn-out, we performed a $\chi^{2}$ test (or Fischer's exact test when $\mathrm{n}<5$ ) for the qualitative variables and a Student's t-test for the quantitative variables. Following the principle of parsimony, we omitted redundant items in the questionnaire to perform multivariate analysis. We conducted two stepwise binary logistic regressions backwards. The first one included the changes in work and lifestyle conditions that could trigger burn-out. The second one included behaviours and thoughts that may be regarded as consequences of burn-out. We considered $\mathrm{p}<0.05$ to be statistically significant. The analysis was performed using the SPSS V. 22.0 software package (SPSS, Chicago, Illinois, USA).

\section{Ethics statement}

The survey was anonymous, and all participants accepted the use of their responses for publication and scientific studies. We requested the explicit approval of the Gregorio Marañón Hospital's Ethics Committee. However, they answered that due to the characteristics of the study (anonymous voluntary survey, without confidentiality issues), it was ethical and no explicit approval was needed. They have sent a favourable report that is available as online supplemental file 1. The study followed the criteria of the Helsinki Declaration. 


\section{RESULTS}

\section{Demographic characteristics}

A total of 1497 internists accessed the form and 1015 of them (250 residents, 702 Internal Medicine specialists, 60 heads of department and 2 Chief Medical Officer) filled in the survey, representing all the autonomous communities in Spain. Of those, $62.9 \%$ were women. The mean age was $39.9 \pm 11.1$ years, $77.2 \%$ were married or had a stable partner, $47.1 \%$ had children and $9.6 \%$ lived with older dependent people. Table 1 shows the demographic characteristics and working conditions of the studied population. We do not have the data of the people who accessed the form but did not fill it in, due to the anonymity of the survey.

\section{Change in work and lifestyle conditions due to the COVID-19 outbreak}

Of the internists who answered, $92.2 \%$ treated patients infected with SARS-CoV-2, 73.2\% experienced an increase in their usual responsibilities (only officially recognised in $11.5 \%$ of cases) and $81.3 \%$ underwent an increase in weekly working hours. Only $27.9 \%$ of the internists received financial compensation for overtime. Free time after 24-hour shifts was not respected in $13.9 \%$ of cases, and only $36.1 \%$ had gone on holidays in the previous 6 months.

Of those who filled the survey, 29.6\% did not have access to PPE when they needed it, $86.8 \%$ were afraid of infecting their families because of their job, and $29.8 \%$ decided to change their usual place of residence to be separated from their families. Finally, 176 Internal Medicine physicians $(17.4 \%)$ presented with SARS-CoV-2 infection confirmed by PCR test. Of these, 15 physicians required hospitalisation and only 1 required admission to an intensive care unit.

Of the participants $21.4 \%$ consumed more alcohol or started consuming alcohol during the pandemic, $7.9 \%$ smoked more tobacco or started smoking, $18.6 \%$ used sleeping pills on a regular basis.

Although $79.0 \%$ of the respondents would still choose Internal Medicine as a specialty, $39.1 \%$ have considered a change of specialty, $44.7 \%$ have considered working abroad and $60.0 \%$ have thought of leaving the medical profession.

\section{Burn-out syndrome and related factors}

Of those who responded (1015), 58.3\% presented with high emotional exhaustion, $61.5 \%$ had a high level of depersonalisation and $67.6 \%$ reported low personal fulfilment. A total of 407 internists (40.1\%) presented with the three previous criteria, and therefore burn-out syndrome. All Maslach Burnout Inventory results are shown in table 2.

Table 3 shows the distribution of the main items of the questionnaire and its distribution among physicians that had a burn-out syndrome according to the Maslach Burnout Inventory.
Table 1 Demographic characteristics and work conditions

\begin{tabular}{|c|c|c|}
\hline & $\begin{array}{l}\text { Number of } \\
\text { responders } \\
(1015)\end{array}$ & $\begin{array}{l}\text { Number (\%) } \\
\text { or median } \\
\text { (IQR) }\end{array}$ \\
\hline Age & 975 & $37(31-47)$ \\
\hline Sex & 1015 & \\
\hline Female & & $638(62.9)$ \\
\hline Male & & $377(37.1)$ \\
\hline Civil status & 1011 & \\
\hline Single & & $231(22.9)$ \\
\hline Married & & $446(44.1)$ \\
\hline Stable partner (not married) & & $334(33.0)$ \\
\hline Partner is healthcare worker & 934 & \\
\hline No & & $525(56.2)$ \\
\hline Yes & & $409(43.8)$ \\
\hline Children & 1009 & \\
\hline No & & $534(52.9)$ \\
\hline Yes & & $475(47.1)$ \\
\hline Living with elderly person & 1012 & \\
\hline No & & $915(90.4)$ \\
\hline Yes & & $97(9.6)$ \\
\hline $\begin{array}{l}\text { Being forced to separate from } \\
\text { your family }\end{array}$ & 1014 & \\
\hline No & & $712(70.2)$ \\
\hline Yes & & $302(29.8)$ \\
\hline Afraid of infecting their family & 1005 & \\
\hline No & & $133(13.2)$ \\
\hline Yes & & $872(86.8)$ \\
\hline Current position & 1014 & \\
\hline Resident doctor & & $250(24.7)$ \\
\hline Medical specialist & & $702(69.2)$ \\
\hline Service head & & $60(5.9)$ \\
\hline Medical director & & $2(0.2)$ \\
\hline Assisted patients with COVID-19 & 1010 & \\
\hline No & & $79(7.8)$ \\
\hline Yes & & $931(92.2)$ \\
\hline Infected with SARS-CoV-2 & 1009 & \\
\hline No & & $833(52.6)$ \\
\hline Yes & & $176(17.4)$ \\
\hline $\begin{array}{l}\text { Need of admission in } \\
\text { hospitalisation ward }\end{array}$ & 342 & \\
\hline No & & $327(95.6)$ \\
\hline Yes & & $15(4.4)$ \\
\hline $\begin{array}{l}\text { Need of admission in intensive } \\
\text { care unit }\end{array}$ & 237 & \\
\hline No & & $236(99.6)$ \\
\hline Yes & & $1(0.4)$ \\
\hline Access to PPE when needed & 1003 & \\
\hline
\end{tabular}

Continued 


\section{Table 1 Continued}

\begin{tabular}{|c|c|c|}
\hline & $\begin{array}{l}\text { Number of } \\
\text { responders } \\
(1015)\end{array}$ & $\begin{array}{l}\text { Number (\%) } \\
\text { or median } \\
\text { (IQR) }\end{array}$ \\
\hline No & & $295(29.4)$ \\
\hline Yes & & 708 (70.6) \\
\hline Type of hospital & 1014 & \\
\hline Public & & $892(88.0)$ \\
\hline Private & & $68(6.7)$ \\
\hline Both & & $54(5.3)$ \\
\hline Hospital size & 1006 & \\
\hline Regional hospital & & $257(25.5)$ \\
\hline Secondary hospital & & $234(23.3)$ \\
\hline Tertiary hospital & & $510(5.7)$ \\
\hline Research centre/university & & $5(0.5)$ \\
\hline $\begin{array}{l}\text { Commute time (from home to } \\
\text { workplace) }\end{array}$ & 1012 & \\
\hline Less than 1 hour from home & & $958(94.3)$ \\
\hline More than 1 hour from home & & $58(5.7)$ \\
\hline Means of transportation to work & 1011 & \\
\hline On foot & & $232(22.9)$ \\
\hline By car & & $611(60.4)$ \\
\hline Bicycle & & $22(2.2)$ \\
\hline Motorcycle & & $13(1.3)$ \\
\hline Public transport & & $132(13.1)$ \\
\hline Working from home & & $1(0.1)$ \\
\hline $\begin{array}{l}\text { More responsibility at work } \\
\text { during pandemic }\end{array}$ & 1011 & \\
\hline No & & $271(26.8)$ \\
\hline Yes & & 740 (73.2) \\
\hline $\begin{array}{l}\text { Recognition of increased } \\
\text { responsibility }\end{array}$ & 737 & \\
\hline No & & $652(88.5)$ \\
\hline Yes & & $85(11.5)$ \\
\hline $\begin{array}{l}\text { Increase in weekly working hours } \\
\text { during pandemic }\end{array}$ & 1010 & \\
\hline No & & $189(18.7)$ \\
\hline Yes & & $821(81.3)$ \\
\hline $\begin{array}{l}\text { Economic compensation for } \\
\text { overtime }\end{array}$ & 913 & \\
\hline No & & $658(72.1)$ \\
\hline Yes & & $255(27.9)$ \\
\hline Rest after 24-hour shifts & 997 & \\
\hline No & & $139(13.9)$ \\
\hline Yes & & $858(86.1)$ \\
\hline Holidays in the last 6 months & 1011 & \\
\hline No & & $646(63.9)$ \\
\hline Yes & & $365(36.1)$ \\
\hline
\end{tabular}

Table 1 Continued

\begin{tabular}{llc|}
\hline & $\begin{array}{l}\text { Number of } \\
\text { responders } \\
\text { (1015) }\end{array}$ & $\begin{array}{l}\text { Number (\%) } \\
\text { (IQR) }\end{array}$ \\
\hline $\begin{array}{l}\text { Type of work contract } \\
\text { Until the end of COVID-19 } \\
\text { pandemic }\end{array}$ & 814 & \\
\hline Less than a month & & \\
\hline 1 month & $13(1.6)$ \\
\hline 3 months & $22(2.7)$ \\
\hline 6 months & $27(3.3)$ \\
\hline More than 6 months & & $42(5.2)$ \\
\hline Permanent & $170(20.9)$ \\
\hline Physical activity per week & 1013 & $515(63.3)$ \\
\hline Never or almost never & & $508(50.1)$ \\
\hline Once & & $128(12.6)$ \\
\hline Twice or thrice & & $267(26.4)$ \\
\hline Everyday & & $110(10.9)$ \\
\hline Leisure activity per week & 1013 & \\
\hline Never or almost never & & $426(42.1)$ \\
\hline Once & & $193(19.0)$ \\
\hline Twice or thrice & & $240(23.7)$ \\
\hline Everyday & & $154(15.2)$ \\
\hline Need for sleeping pills & 1011 & \\
\hline No & & $823(81.4)$ \\
\hline Yes & & $188(18.6)$ \\
\hline Use of antidepressant drugs & 1010 & \\
\hline No & & $952(94.3)$ \\
\hline Yes & & $58(5.7)$ \\
\hline
\end{tabular}

Change in smoking habits during 816 pandemic

$\begin{array}{lc}\text { Same } & 741(90.8) \\ \text { Less } & 11(1.4) \\ \text { More } & 46(5.7) \\ \text { Start smoking } & 18(2.2)\end{array}$

Change in alcohol consumption $\quad 979$ during pandemic

\begin{tabular}{lc} 
Same & $662(67.6)$ \\
Less & $108(11.0)$ \\
More & $180(18.4)$ \\
\hline $\begin{array}{l}\text { Start taking alcohol } \\
\text { Use of recreational drugs }\end{array}$ & $29(3.0)$ \\
$\quad$ No & \\
Yes & $993(98.5)$ \\
Choosing internal medicine again 1008 & $15(1.5)$ \\
No & \\
Yes & $212(21.0)$ \\
\hline
\end{tabular}

Continued 
Table 1 Continued

\begin{tabular}{|c|c|c|}
\hline & $\begin{array}{l}\text { Number of } \\
\text { responders } \\
(1015)\end{array}$ & $\begin{array}{l}\text { Number (\%) } \\
\text { or median } \\
\text { (IQR) }\end{array}$ \\
\hline $\begin{array}{l}\text { Having thought of changing } \\
\text { specialty }\end{array}$ & 1011 & \\
\hline No & & $616(60.9)$ \\
\hline Yes & & 395 (39.1) \\
\hline $\begin{array}{l}\text { Having thought of working } \\
\text { abroad }\end{array}$ & 1008 & \\
\hline No & & $451(44.7)$ \\
\hline Yes & & 557 (55.3) \\
\hline $\begin{array}{l}\text { Having thought of abandoning } \\
\text { medicine }\end{array}$ & 1009 & \\
\hline No & & $404(40.0)$ \\
\hline Yes & & $605(60.0)$ \\
\hline
\end{tabular}

PPE, personal protective equipment.

The demographic and work conditions regarded as trigger factors related to burn-out syndrome and its multivariate analysis are shown in table 4 . Burn-out syndrome was independently related to the management of patients with SARS-CoV-2 (HR: 2.26; 95\% CI 1.15 to 4.45), the lack of availability of PPE (HR: 1.41; 95\% CI 1.05 to 1.91), increased responsibility (HR: 2.13; $95 \%$ CI 1.51 to 3.01 ), not having received financial compensation for overtime work (HR: $0.43 ; 95 \% \mathrm{CI} 0.31$ to 0.62 ), not having rested after shifts (HR: 1.61; 95\% CI 1.09 to 2.38), not having had holidays in the previous 6 months (HR: 1.36; 95\% CI 1.01 to 1.84 ) and having used public transport to commute (HR: $1.96 ; 95 \%$ CI 1.30 to 2.95 ).

Moreover, we present in table 5 the multivariate analysis of habits and thoughts that can be considered consequences of burn-out syndrome. Physicians with burn-out syndrome were independently associated with consumption of sleeping pills (HR: $1.83 ; 95 \%$ CI 1.28 to 2.63 ), higher alcohol intake (HR: 1.95; 95\% CI 1.39 to 2.73), increased desire to change medical specialty (HR: 1.87; $95 \%$ CI 1.38 to 2.54$)$ and a greater desire to quit the medical profession (HR: 1.87; 95\% CI 1.38 to 2.56).

\section{DISCUSSION}

More than $90 \%$ of the Spanish internists treated patients with SARS-CoV-2, and most of them experienced changes in their work and personal life caused by the outbreak. Excessive work and fear of being contagious to their relatives increased stress and resulted in burn-out.

More than 90000 people in Spain were hospitalised from February to May 2020 due to SARS-CoV-2 infection and more than 7000 had to be admitted to intensive care units. ${ }^{4}$ Spanish hospitals were overcrowded, without enough beds or ventilators for all the patients who needed

\begin{tabular}{|c|c|c|}
\hline & Number of responders (1015) & $\mathbf{N}(\%)$ \\
\hline Emotional exhaustion, score & 1015 & \\
\hline Low (0-18) & & $232(22.9)$ \\
\hline Medium (19-26) & & $191(18.8)$ \\
\hline High (27-54) & & $592(58.3)$ \\
\hline Depersonalisation, score & 1015 & \\
\hline Low (0-33) & & $185(18.2)$ \\
\hline Medium(6-9) & & $206(23.2)$ \\
\hline High (10-30) & & $624(61.5)$ \\
\hline Personal accomplishment, score & 1015 & \\
\hline Low (0-33) & & $686(67.6)$ \\
\hline Medium (34-39) & & $235(23.1)$ \\
\hline High (40-56) & & $94(9.3)$ \\
\hline Burn-out syndrome & 1015 & \\
\hline No & & $608(59.9)$ \\
\hline Yes & & $407(40.1)$ \\
\hline Burn-out syndrome in residents & 250 & \\
\hline No & & $135(54.0)$ \\
\hline Yes & & $115(46.0)$ \\
\hline Burn-out syndrome in specialists & 764 & \\
\hline No & & $472(61.8)$ \\
\hline Yes & & $292(38.2)$ \\
\hline
\end{tabular}


Table 3 Distribution of different included characteristics in the survey according to burn-out

\begin{tabular}{|c|c|c|c|c|}
\hline Variable & $\begin{array}{l}\text { All }(n=1015) \\
\text { Median IQR or } \\
\text { number/total (\%) }\end{array}$ & $\begin{array}{l}\text { No burn-out }(n=609) \\
\text { Median IQR or } \\
\text { number/total (\%) }\end{array}$ & $\begin{array}{l}\text { Burn-out }(n=406) \\
\text { Median IQR or } \\
\text { number/total (\%) }\end{array}$ & $P$ value \\
\hline \multicolumn{5}{|l|}{ Demographics } \\
\hline Age (years) & $37(31-47)$ & $38(31-48)$ & $36(30-44)$ & 0.002 \\
\hline Female & $638 / 1015(62.9 \%)$ & $371 / 609(60.9 \%)$ & $266 / 406(65.5 \%)$ & 0.138 \\
\hline Stable partner (married or unmarried) & $780 / 1011(77.2 \%)$ & 478/608 (78.6\%) & $302 / 403(74.9 \%)$ & 0.172 \\
\hline Partner is healthcare worker & $525 / 934(56.2 \%)$ & $315 / 558$ (56.5\%) & 209/376 (55.6\%) & 0.794 \\
\hline Children & $474 / 1009$ (47\%) & $308 / 605$ (50.9\%) & $166 / 404$ (41.1\%) & 0.002 \\
\hline Living with elderly person & 97/1012 (9.6\%) & $51 / 607(8.4 \%)$ & 46/407 (11.4\%) & 0.118 \\
\hline Being forced to separate from your family & $302 / 1014$ (29.8\%) & $168 / 609(27.6 \%)$ & $134 / 406(33.1 \%)$ & 0.061 \\
\hline Afraid of infecting their family & $872 / 1005$ (86.8\%) & $506 / 601$ (84.2\%) & $366 / 404$ (90.6\%) & 0.003 \\
\hline Infected with SARS-CoV-2 & 176/1009 (17.4\%) & 103/605 (17\%) & 73/404 (18.1\%) & 0.668 \\
\hline \multicolumn{5}{|l|}{ Work conditions } \\
\hline Resident doctor & $250 / 1014$ (24.7\%) & 135/609 (22.2\%) & 115/406 (28.3\%) & 0.026 \\
\hline Medical specialist & $702 / 1014$ (69.2\%) & $426 / 609$ (70\%) & $276 / 406$ (68\%) & 0.026 \\
\hline Service head & $60 / 1014$ (5.9\%) & $46 / 609$ (7.6\%) & $14 / 406(3.5 \%)$ & 0.026 \\
\hline Medical director & 2/1014 (0.2\%) & $1 / 609(0.2 \%)$ & $1 / 406(0.2 \%)$ & 0.026 \\
\hline Regional hospital & 257/1006 (25.5\%) & 149/609 (24.5\%) & $108 / 406(26.6 \%)$ & 0.228 \\
\hline Secondary hospital & $234 / 1006$ (23.3\%) & 145/609 (23.8\%) & $88 / 406(21.7 \%)$ & 0.228 \\
\hline Tertiary hospital & $510 / 1006(50.3 \%)$ & $303 / 609(49.8 \%)$ & 208/406 (51.2\%) & 0.228 \\
\hline Research centre/medical school & $5 / 1006(0.5 \%)$ & $4 / 609(0.7 \%)$ & $1 / 406(0.2 \%)$ & 0.228 \\
\hline Time to work $>1$ hour & $58 / 1012(5.7 \%)$ & $25 / 607(4.1 \%)$ & $33 / 405$ (8.1\%) & 0.007 \\
\hline On foot to work & $232 / 1011$ (22.9\%) & $146 / 609$ (24\%) & $85 / 406(20.9 \%)$ & 0.009 \\
\hline By car to work & $611 / 1011(60.4 \%)$ & $367 / 609$ (60.3\%) & $244 / 406$ (60.1\%) & 0.009 \\
\hline Public transport to work & $132 / 1011(13.1 \%)$ & $66 / 609(10.8 \%)$ & $67 / 406(16.5 \%)$ & 0.009 \\
\hline Bicycle to work & $22 / 1011(2.2 \%)$ & $13 / 609(2.1 \%)$ & $9 / 406(2.2 \%)$ & 0.009 \\
\hline Motorcycle to work & $13 / 1011(1.3 \%)$ & $13 / 609(2.1 \%)$ & $0 / 406(0 \%)$ & 0.009 \\
\hline Assisted patients with COVID-19 & $931 / 1010$ (92.2\%) & $544 / 606$ (89.8\%) & $387 / 404$ (95.8\%) & $<0.001$ \\
\hline More responsibility at work during pandemic & $740 / 1011(73.2 \%)$ & $406 / 607$ (66.9\%) & $334 / 404$ (82.7\%) & $<0.001$ \\
\hline Recognition of increased responsibility & $85 / 737(11.5 \%)$ & $63 / 408(15.4 \%)$ & $22 / 329(6.7 \%)$ & $<0.001$ \\
\hline Number of patients per day & $10(8-12)$ & $10(8-12)$ & $10(8-12)$ & 0.345 \\
\hline No access to PPE when needed & 295/1003 (29.4\%) & $151 / 601(25.1 \%)$ & 144/258 (35.8\%) & $<0.001$ \\
\hline Increase in weekly working hours work & $821 / 1010$ (81.3\%) & $475 / 604(78.6 \%)$ & $346 / 406$ (85.2\%) & 0.009 \\
\hline Guard hours per week & $32(15-52)$ & $30(14-50)$ & $40(16.5-56)$ & 0.009 \\
\hline Economical compensation for overtime & $257 / 913(28.1 \%)$ & 188/538 (34.9\%) & $69 / 375(18.4 \%)$ & $<0.001$ \\
\hline No rest after 24-hour shift & 139/997 (13.9\%) & 65/594 (10.9\%) & $74 / 403(18.4 \%)$ & 0.001 \\
\hline Not having 48 hours per week to rest & $582 / 1003(58 \%)$ & $318 / 599$ (53.1\%) & $264 / 404$ (65.3\%) & $<0.001$ \\
\hline Free days in the last month & $6(4-7)$ & $6(4-7)$ & $5(3-6)$ & $<0.001$ \\
\hline No holiday in the last 6 months & $646 / 1011$ (63.9\%) & $369 / 606$ (60.9\%) & $276 / 405$ (68.1\%) & 0.019 \\
\hline Stable contract & $514 / 1015$ (50.6\%) & $328 / 609$ (53.9\%) & $186 / 406(45.8 \%)$ & 0.012 \\
\hline \multicolumn{5}{|l|}{ Habits and thoughts } \\
\hline Physical or any leisure activity twice a week & $559 / 1015$ (55.1\%) & $356 / 609$ (58.5\%) & $203 / 406$ (50\%) & 0.008 \\
\hline $\begin{array}{l}\text { More tobacco (increased consumption or } \\
\text { started to consume) }\end{array}$ & $64 / 1015(6.3 \%)$ & $31 / 609(5.1 \%)$ & $33 / 406(8.1 \%)$ & 0.051 \\
\hline $\begin{array}{l}\text { More alcohol (increased consumption or } \\
\text { started to consume) }\end{array}$ & $209 / 1015$ (20.6\%) & $96 / 609(15.8 \%)$ & $113 / 406(27.8 \%)$ & $<0.001$ \\
\hline
\end{tabular}


Table 3 Continued

\begin{tabular}{llll}
\hline & $\begin{array}{l}\text { All (n=1015) } \\
\text { Median IQR or } \\
\text { number/total (\%) }\end{array}$ & $\begin{array}{l}\text { No burn-out (n=609) } \\
\text { Median IQR or } \\
\text { number/total (\%) }\end{array}$ & $\begin{array}{l}\text { Burn-out (n=406) } \\
\text { Median IQR or } \\
\text { number/total (\%) }\end{array}$ \\
\hline P value
\end{tabular}

All variables in italics are significantly $(p<0.05)$ related to burn-out syndrome.

$\mathrm{PPE}$, personal protective equipment.

them. Health workers had to work longer shifts and their responsibility increased. This was especially important in Internal Medicine, the specialty that generally treats infectious diseases in Spain.

This situation caused increased stress and ethical dilemmas when deciding which patients were candidates for intensive care units. Additionally, physicians faced an unknown new infectious disease without enough personal protective material. In fact, $29.6 \%$ of the respondents did not have access to PPE when they needed it. In our survey, $17.4 \%$ of the respondents presented with SARS-CoV-2 infection confirmed by PCR analysis, and 15 cases reported severe disease.

All these factors increased the number of Internal Medicine physicians who presented with burn-out syndrome. One year ago, the prevalence in Spain was $33.4 \%,{ }^{10}$ and in the actual survey the prevalence is $40.1 \%$.

Other previous studies ${ }^{14-17}$ also showed increased stress during the COVID-19 outbreak. Only a single Chinese study ${ }^{18}$ showed that burn-out syndrome prevalence was lower in professionals who worked on the first line. They discussed that this was possibly related to the fact that these professionals had more knowledge about the disease, more sense of control of the situation and more social recognition. In our study we have found the opposite results. This is probably due to shortage of PPE and low level of social recognition in Spain. In fact, the factors related to burn-out syndrome were those related to fear of contagion (managing patients with SARS-CoV-2, not having access to PPE and using public transport to commute) and those related to overworking without sufficient recognition (increased responsibility, not resting after shifts and not having financial compensation for overtime work).

Moreover, the pandemic hit Europe right after the influenza season, when health workers were already tired and stressed from the overwork of the winter season. In fact, not having had any holidays in the previous 6 months was related to higher burn-out scores.

As previous studies have found, ${ }^{7} 1920$ burn-out had important consequences on the health of professionals, such as anxiety, depression, substance abuse or development of psychosomatic symptoms. In fact, we also found that burn-out was related to increased consumption of alcohol and sleeping drugs.

Moreover, doctors who had high levels of burn-out were less satisfied with their job and, similarly to previous studies, ${ }^{1011}$ we found that they would be more willing to change their medical specialty or abandon the medical profession. Furthermore, there are studies that have found a reduction in the productivity and efficiency of medical care and an increase in medical errors. ${ }^{21} 22$

Therefore, it is important to initiate programmes to prevent and treat burn-out in front-line physicians during the COVID-19 outbreak. ${ }^{23-25}$ In general, two different types of stress reduction measures have been previously studied: those that focus on work organisation and those that focus on the individual. The first group includes measures such as reducing the number of shift hours, increasing professional recognition, rotation between different kinds of work and the implementation of equity policies. $^{22} 2627$ The second includes measures such as promotion techniques to handle stressful situations, meditation techniques, communication skills and cognitive-behavioral therapy. ${ }^{1128-30}$

The main limitation of our study is that it was carried out through a voluntary online survey. It is possible that the most affected doctors were the most interested in answering the survey and, therefore, the prevalence of burn-out could have been overestimated. However, since our results were similar to those of previous studies, ${ }^{729}$ the high number of responders may have mitigated this effect. In addition, according to the design of the study, cause-effect relation of the variables can only be suggested and not categorically established. Moreover, the survey was distributed through SEMI's social networks and the mailing list of the members of SEMI. The fact that this survey has been carried online and on a voluntary basis could have led to a higher number of answers by young people; nevertheless the distribution of ages of the sample was similar to the distribution of all the internists of the society. 


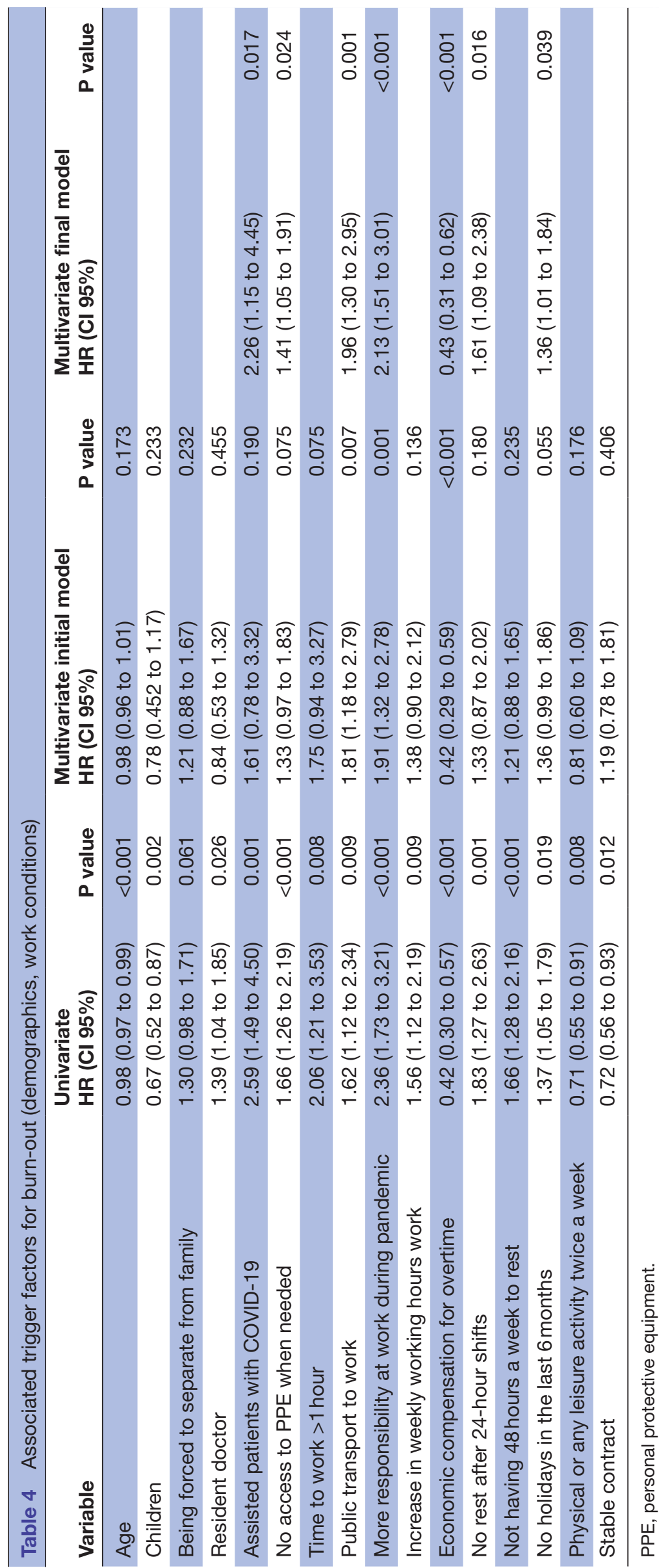


In conclusion, during the COVID-19 outbreak more than $40 \%$ of Internal Medicine physicians in Spain presented with burn-out syndrome. The development of burn-out syndrome was independently related to the assistance of patients with SARS-CoV-2, the lack of PPE, greater responsibility during the outbreak, the absence of financial compensation despite working overtime, the absence of rest after 24-hour shifts, not having had holidays in the previous 6 months and the use of public transport to commute.

\section{Author affiliations}

${ }^{1}$ Department of Internal Medicine, POVISA Hospital-Ribera Salud Group, Vigo, Spain ${ }^{2}$ Formation Work Group of the Spanish Society of Internal Medicine, Madrid, Spain ${ }^{3}$ Department of Internal Medicine, Hospital General Universitario Gregorio Marañón, Madrid, Spain

${ }^{4}$ Autoimmune Diseases Research Unit, Department of Internal Medicine, Biocruces Bizkaia Health Research Institute, Hospital Universitario Cruces, Barakaldo, Spain ${ }^{5}$ Department of Internal Medicine, Complexo Hospitalario Universitario de Santiago de Compostela, Santiago de Compostela, Spain

${ }^{6}$ Chief Medical Officer, Hospital Real Nuestra Señora de Gracia, Zaragoza, Spain

Acknowledgements The authors thank the Spanish healthcare workers involved in assistance with the SARS-CoV-2 pandemic for their effort and dedication.

Contributors CM-R and AAdO designed the survey, wrote the statistical analysis plan, cleaned and analysed the data, and drafted and revised the paper. CM- $R$ is the guarantor. MTP-S wrote the statistical analysis plan, analysed the data, and drafted and revised the paper. LB-L and MTP-S drafted and revised the paper. JM-D and AG-M revised the paper.

Funding This research was funded by the Spanish Society of Internal Medicine. Competing interests None declared.

Patient consent for publication Not required.

Provenance and peer review Not commissioned; externally peer reviewed.

Data availability statement Data are available upon reasonable request. Anyone who wishes to look at the data can contact the authors directly who will provide the database containing all information needed to reproduce the study.

Supplemental material This content has been supplied by the author(s). It has not been vetted by BMJ Publishing Group Limited (BMJ) and may not have been peer-reviewed. Any opinions or recommendations discussed are solely those of the author(s) and are not endorsed by BMJ. BMJ disclaims all liability and responsibility arising from any reliance placed on the content. Where the content includes any translated material, BMJ does not warrant the accuracy and reliability of the translations (including but not limited to local regulations, clinical guidelines, terminology, drug names and drug dosages), and is not responsible for any error and/or omissions arising from translation and adaptation or otherwise.

Open access This is an open access article distributed in accordance with the Creative Commons Attribution Non Commercial (CC BY-NC 4.0) license, which permits others to distribute, remix, adapt, build upon this work non-commercially, and license their derivative works on different terms, provided the original work is properly cited, appropriate credit is given, any changes made indicated, and the use is non-commercial. See: http://creativecommons.org/licenses/by-nc/4.0/.

ORCID iD

Cristina Macía-Rodríguez http://orcid.org/0000-0001-9032-7127

\section{REFERENCES}

1 Wu D, Wu T, Liu Q, et al. The SARS-CoV-2 outbreak: what we know. Int $J$ Infect Dis 2020;94:44-8.

2 Tan BYQ, Chew NWS, Lee GKH, BYQ T, GKH L, et al. Psychological impact of the COVID-19 pandemic on health care workers in Singapore. Ann Intern Med 2020;173:317-20.

3 Guan W-J, Ni Z-Y, Hu Y, et al. Clinical characteristics of coronavirus disease 2019 in China. N Engl J Med 2020;382:1708-20. 
4 Spiteri G, Fielding J, Diercke M, et al. First cases of coronavirus disease 2019 (COVID-19) in the who European region, 24 January to 21 February 2020. Euro Surveill 2020;25:2000178.

5 Instituto Carlos III. [Análisis de los casos de COVID-19 notificados a la RENAVE hasta el 10 de mayo en España Contenido], 2020. Available: https://www.isciii.es/QueHacemos/Servicios/Vigilanc iaSaludPublicaRENAVE/EnfermedadesTransmisibles/Documents/ INFORMES/Informes\%20COVID-19/Informe\%20n\%C2\%BA\% 2033.\%20An\%C3\%A1lisis\%20de\%20los\%20casos\%20de\% 20COVID-19\%20hasta\%20el\%2010\%20de\%20mayo\%20en\% 20Espa\%C3\%B1a\%20a\%2029\%20de\%20mayo\%20de\%202020. pdf

6 Rodrigues $\mathrm{H}$, Cobucci R, Oliveira A, et al. Burnout syndrome among medical residents: a systematic review and meta-analysis. PLoS One 2018;13:e0206840.

7 Yates M, Samuel V. Burnout in oncologists and associated factors: a systematic literature review and meta-analysis. Eur J Cancer Care 2019;28:e13094.

8 Freudenberger HJ. Staff burn-out. J Soc Issues 1974;30:159-65.

9 Maslach C, Schaufeli WB, Leiter MP. Job burnout. Annu Rev Psychol 2001;52:397-422.

10 Macía-Rodríguez C, Martín Iglesias D, Moreno Diaz J, et al. Burnout syndrome in internal medicine specialists and factors associated with its onset. Rev Clin Esp 2020;220:331-338.

11 Maslach C, Leiter MP. New insights into burnout and health care: strategies for improving civility and alleviating burnout. Med Teach 2017;39:160-3.

12 Maslach C, Leiter MP, Schaufeli W. Measuring burnout. Oxford: Oxford University Press, 2008.

13 Low ZX, Yeo KA, Sharma VK, et al. Prevalence of burnout in medical and surgical residents: a meta-analysis. Int J Environ Res Public Health 2019;16:1479.

14 Lai X, Wang M, Qin C, et al. Coronavirus disease 2019 (COVID-2019) infection among health care workers and implications for prevention measures in a tertiary hospital in Wuhan, China. JAMA Netw Open 2020;3:e209666.

15 Abdessater M, Rouprêt M, Misrai V, et al. COVID19 pandemic impacts on anxiety of French urologist in training: outcomes from a national survey. Prog Urol 2020;30:448-55.

16 Civantos AM, Byrnes Y, Chang C, et al. Mental health among otolaryngology resident and attending physicians during the COVID-19 pandemic: national study. Head Neck 2020;42:1597-609.
17 Mijiritsky E, Hamama-Raz Y, Liu F, et al. Subjective overload and psychological distress among dentists during COVID-19. Int $J$ Environ Res Public Health 2020;17:5074.

18 Wu Y, Wang J, Luo C, et al. A comparison of burnout frequency among oncology physicians and nurses working on the frontline and usual wards during the COVID-19 epidemic in Wuhan, China. J Pain Symptom Manage 2020;60:e60-5.

19 Medscape. Medscape global physicians' burnout and lifestyle comparisons, 2020. Available: https://www.medscape.com/ slideshow/2019-global-burnout-comparison-6011180

20 Koutsimani P, Montgomery A, Georganta K. The relationship between burnout, depression, and anxiety: a systematic review and metaanalysis. Front Psychol 2019;10:284.

21 Shanafelt TD, Mungo M, Schmitgen J, et al. Longitudinal study evaluating the association between physician burnout and changes in professional work effort. Mayo Clin Proc 2016;91:422-31.

22 Bridgeman PJ, Bridgeman MB, Barone J. Burnout syndrome among healthcare professionals. Am J Heal Pharm 2018;75:147-52.

23 Blake $\mathrm{H}$, Bermingham F, Johnson G, et al. Mitigating the psychological impact of covid-19 on healthcare workers: a digital learning package. Int J Environ Res Public Health 2020;17. doi:10.3390/ijerph17092997. [Epub ahead of print: 2604 2020].

24 Shah K, Chaudhari G, Kamrai D, et al. How essential is to focus on physician's health and burnout in coronavirus (COVID-19) pandemic? Cureus 2020;12:e7538. doi:10.7759/cureus.7538

25 Fessell D, Cherniss C. Coronavirus disease 2019 (COVID-19) and beyond: Micropractices for burnout prevention and emotional wellness. J Am Coll Radiol 2020;17:746-8. doi:10.1016/j. jacr.2020.03.013

26 Ripp JA, Bellini L, Fallar R, et al. The impact of duty hours restrictions on job burnout in internal medicine residents: a three-institution comparison study. Acad Med 2015;90:494-9.

27 West CP, Dyrbye LN, Erwin PJ, et al. Interventions to prevent and reduce physician burnout: a systematic review and meta-analysis. Lancet 2016;388:2272-81.

28 Palamara K, Kauffman C, Stone VE, et al. Promoting success: a professional development coaching program for interns in medicine. $J$ Grad Med Educ 2015;7:630-7.

29 The Lancet. Physician burnout: a global crisis. Lancet 2019;394:93.

$30 \mathrm{Ho}$ CS, Chee CY, Ho RC, CS H, RC H. Mental health strategies to combat the psychological impact of COVID-19 beyond paranoia and panic. Ann Acad Med Singap 2020;49:155-60. 